\title{
REFLEXÕES SOBRE ESTILO EM SOCIOLINGUÍSTICA: UM ESTUDO SOBRE O LIVRO CAPÃO PECADO, DE FERRÉZ*
}

\author{
REFLEXIONES ACERCA DEL ESTILO EN SOCIOLINGÜÍSTICA: UN ESTUDIO ACERCA DEL LIBRO CAPÃO \\ PECADO, DE FERRÉZ
}

\author{
REFLECTIONS ON STYLE IN SOCIOLINGUISTICS: A STUDY ABOUT THE BOOK CAPÃO PECADO, BY \\ FERRÉZ
}

Marco Antônio Rosa Machado**

Universidade Estadual de Goiás - UEG, Anápolis, BR

\begin{abstract}
RESUMO: Este trabalho tem como objetivo principal elaborar algumas reflexões sobre a noção de estilo em sociolinguística e demonstrar como o estilo atua na constituição e na representação de personae sociais, no interior de grupos sociolinguísticos determinados. Tendo em vista que estilo é concebido em linhas gerais como as diferenciações de comportamento linguístico que iconicamente refletem diferenciações (contrastes) sociais, buscamos analisar algumas ocorrências lexicais no livro Capão Pecado, de Ferréz, para entender como os estilos, os registros linguísticos e a variação dialetal de ordem lexical nele presentes contribuem, em alguma medida, para a constituição identitária do homem que vive na periferia.

PALAVRAS-CHAVE: Sociolinguística; estilo linguístico; variação dialetal.
\end{abstract}

RESUMEN: Este trabajo tiene como principal objetivo desarrollar una reflexión sobre la noción de estilo en la sociolingüística y demostrar cómo el estilo actúa en la constitución y representación de personae sociales dentro de ciertos grupos sociolingüísticos. Teniendo en cuenta que el estilo es concebido en términos generales como la diferenciación de comportamientos lingüísticos que reflejan icónicamente diferencias sociales (contrastes), se analizan algunas ocurrencias léxicas en el libro Capão Pecado, escrito por Ferréz, para entender cómo los estilos, los registros lingüísticos y la variación dialectal del léxico presentes en él contribuyen en cierta medida a la formación de la identidad del hombre que vive en la periferia.

PALABRAS-CLAVE: Sociolingüística; estilo lingüístico; variación dialectal.

ABSTRACT: This article has as its main objectives to develop some reflections about the notion of style in sociolinguistics and to demonstrate how style works in the constitution and representation of social personae within certain sociolinguistic groups. Considering that style is conceived broadly as the differentiations of linguistic behavior that iconically reflect social differences (contrasts), we analyze some lexical occurrences in the book Capão Pecado, by Ferréz, in order to understand how styles, linguistic registers and dialectal lexical variation which are present in that book contribute to some extent to the formation of identity of the man who lives in the suburbs.

KEYWORDS: Sociolinguistics; linguistic style; dialectal variation.

\section{INTRODUÇÃO}

Conforme salientou Bentes (2008), os chamados manos - sujeitos de diferentes faixas etárias e pertencentes a diferentes estratos sociais - vêm "produzindo uma forte identidade para si, afirmando um conjunto heteróclito de repertórios linguísticos e discursivos, de valores sociais, posturas e modos de vida" (BENTES, 2008, p. 1). Tanto as identidades quanto os valores produzidos pelos manos experimentam uma dupla e paradoxal recepção por parte dos grupos onde circulam: se por um lado uma grande massa de pessoas - homens e mulheres da periferia de São Paulo e de outras grandes cidades paulistas - avalia as identidades e os valores dos manos positivamente e os atualiza de diferentes formas, por outro lado outros grupos sociais os rejeitam e deles tentam se afastar e se diferenciar do processo de formação dessa identidade.

\footnotetext{
* Este texto surgiu das longas e proveitosas discussões que tive com Anna Christina Bentes e Renato Cabral Rezende, a quem agradeço de coração. Agradeço ainda a Elisa Battisti, Gisele Cássia de Sousa, Ariovaldo Lopes Pereira e aos dois pareceristas anônimos, que, com seus questionamentos e sugestões, contribuíram enormemente para o formato final deste texto. As imperfeições que ainda perduram são de minha inteira responsabilidade.

** Mestre e doutorando em Linguística pelo Instituto de Estudos da Linguagem da Universidade Estadual de Campinas (IEL/UNICAMP). Professor no Curso de Letras da Universidade Estadual de Goiás (UEG - Anápolis). E-mail: machadorvd@yahoo.com.br.
} 
A busca da constituição, bem como da afirmação de identidade desse grupo, se opera por meio de vários mecanismos que vão desde o estilo musical preferido e produzido pelos manos (o rap, por exemplo), seu modo de vestir (calças largas, blusas de moletom, bonés, etc.), suas interações linguísticas (com vocabulário próprio), até a literatura por eles produzida e distribuída na periferia. É o caso de escritores como Ferréz (pseudônimo de Reginaldo Ferreira da Silva), cuja obra (tanto social quanto literária) ganhou repercussão não só na periferia onde nasceu, mas também na mídia escrita e impressa, nacional e internacional, depois do lançamento de Capão Pecado, publicado no ano de 2000.

Tendo em vista que Capão Pecado constitui um legítimo exemplo da transposição para literatura dessa busca de constituição e valorização da identidade do morador da periferia, o mano, em nosso artigo propomos como objetivo geral analisar algumas características linguísticas desse livro de Ferréz, para tentar entender como o estilo e os registros linguísticos nele presentes contribuem, em alguma medida, para a constituição identitária do homem que vive na periferia - o mano. Para isso, estabelecemos os seguintes objetivos específicos: (i) identificar e contrastar as vozes que se manifestam por meio dos diferentes registros em Capão Pecado, relacionando-as com as personae sociais envolvidas na interação e (ii) indicar, a partir dos mecanismos linguísticos usados (especialmente o vocabulário), como essas vozes se relacionam na obra.

Nossa hipótese inicial de trabalho é que o manejo das diversas vozes presentes no livro constitui estratégia discursiva pela qual o autor/narrador se situa ideologicamente perante o embate de vozes que coloca em confronto constantemente. Acreditamos que o uso de alguns mecanismos linguísticos (principalmente vinculados à variação dialetal de ordem lexical) é central na constituição e situação da voz narradora em relação às demais vozes presentes no livro.

Nesse sentido, interessam-nos as discussões em torno das noções de dialeto, registro e estilo, empreendidas por alguns sociolinguistas contemporâneos, especialmente Irvine (2001), Coupland (2001, 2007), Agha (2005, 2007), Bentes (2008, 2009), com os quais tentaremos dialogar em nosso texto.

\section{ESTILO E VARIAÇÃo EM SOCIOLINGUíSTICA: A CONSTRUÇÃO SOCIAL DO SIGNIFICADO}

O estilo, um dos elementos centrais no estudo da variação linguística desde a constituição do campo da sociolinguística por Labov, ainda constitui problema teórico profícuo e fundamental em linguística. Conforme salienta Bell (1984, p. 145), dentro do paradigma variacionista laboviano, o fenômeno da variação linguística tem sido caracterizado a partir de três componentes principais: (i) componentes internos ao próprio sistema sob análise (fatores imanentes, portanto); (ii) componentes sociais dos falantes, sua classe social, gênero, grau de escolaridade (fatores interfalantes); (iii) fatores de natureza individual (intrafalantes), que constituem o cerne dos componentes estilísticos.

As discussões iniciais no campo da sociolinguística empreendidas por Labov focaram na variação intrafalante e levaram pesquisadores posteriores a definir estilo simplesmente como as variações que um falante individual faz no uso da língua em uma situação monolíngue bastante estruturada (cf. IRVINE, 2001, p. 25). Nessa perspectiva, a variação estilística é constituída a partir de duas características: (i) prestígio e (ii) atenção do falante à própria fala. Embora Labov (2008 [1972]) tenha relacionado prestígio e posição social na qual o falante se situa na hierarquia socioeconômica à variação estilística ${ }^{1}$, isso parece não ter sido suficientemente explicado em estudos sociolinguísticos posteriores.

Irvine (2001, p. 31) concorda que prestígio e atenção à fala não podem ser desconsideradas nos estudos sobre o estilo, mas apenas elas não dão conta do significado estilístico. A autora insiste na questão de que o estilo diz respeito não apenas a elementos linguísticos - como o estilo tradicionalmente tem sido tratado mas também ao contínuo processo de construção de semiose que vai além da língua. Conforme aponta Irvine (2001, p. 26-27), uma consequência teórica do tratamento da variação que considera apenas aquela que ocorre intrafalantes e desconsidera a variação entre falantes é o risco de se confundirem dialeto e registro. Por essa razão, a autora propõe um critério funcional para se distinguir dialeto e registro. Dialetos seriam, nessa perspectiva, as variedades com relação aos usuários, de modo que o dialeto usado por um falante indicaria a sua filiação social a um grupo de falantes - especialmente em relação ao local de origem.

1 A correlação entre prestígio e variação estilística encontra-se exemplificada nos trabalhos de Labov (2008 [1972]) acerca da estratificação social do [r] nas lojas de departamento de Nova York. 
Já os registros seriam as variedades com relação aos usos. O registro usado pelo falante seria indicativo de sua situação social e de sua atividade social - que pode ser tanto uma situação preestabelecida antes da fala, como uma situação que se tenta criar (IRVINE, 2001, p. 27).

Outra questão que, segundo Irvine, está relacionada à distinção entre dialeto e registro diz respeito ao grau de consciência do falante acerca da possibilidade de uso das variedades. A autora afirma que, "por definição, deve haver um conjunto de registros dentro do qual o uso de um falante se alterna, e de cuja existência ele está, até certo grau, consciente" (IRVINE, 2001, p. 28, grifo da autora)2. Já dialeto não implica, necessariamente, consciência do falante acerca das possibilidades alternativas de que a língua dispõe. Isso porque a concepção tradicional de dialeto o vê como uma variedade formada e existente independentemente das demais, o que não ocorre com os registros, cuja existência decorre da oposição - muitas vezes ideologicamente marcada - dos vários registros partilhados (ou ao menos conhecidos) por uma comunidade de fala.

Para Irvine (2001) e Irvine e Gal (2000), a noção de estilo está intimamente ligada a três processos semióticos: distintividade, recursividade e apagamento. Segundo as autoras, os estilos têm a ver com o modo pelo qual os falantes negociam suas posições e seus objetivos dentro de um sistema de possibilidades no espaço social. Diante da constatação de que registros (ou mesmo dialetos) podem ser usados para estabelecer diferenciação, Irvine então sugere que, ao se usar o termo estilo, coloque-se menos ênfase sobre a variedade como objeto em si mesmo e salientem-se os processos de distinção, que operam em vários níveis, desde o mais saliente até o mais sutil. Desse modo, argumenta a autora, o estilo deve incluir não só os padrões e variedades relativamente estáveis e institucionalizados (que inclusive recebem nomes explícitos dentro de sua comunidade de uso), mas também as maneiras mais sutis pelas quais os indivíduos navegam entre as variedades disponíveis e "tentam desempenhar uma representação coerente de um eu distintivo um eu que pode ser, por sua vez, subdivisível em um sistema diferenciado de aspectos do eu" (IRVINE, 2001, p. 31).

Irvine acrescenta ainda uma distinção conceitual que talvez seja central para sua noção de estilo, e que se coloca como uma proposta complementar à visão laboviana:

Enquanto dialeto e registro - ao menos como a sociolinguística ordinariamente os identifica - referemse a fenômenos linguísticos apenas, estilo envolve princípios de distintividade que podem se estender além do sistema linguístico para outros aspectos do comportamento que são organizados semioticamente. (IRVINE, 2001, p. 31-32).

O modelo que Irvine propõe diz respeito ao modo como a semiose social explora traços linguísticos para estabelecer uma distinção a partir da mobilização e interpretação criativas. Irvine, ao comparar suas pesquisas (sobre os Wolof do Senegal) com os trabalhos desenvolvidos por Susan Gal no sul da Hungria, observou o seguinte:

1. O fenômeno linguístico que constitui registros e estilos, como forma de distintividade linguística, tem uma consistência que deriva, em certo grau, de ideologias locais da língua - princípios de distintividade que ligam diferenças linguísticas a significados sociais.

2. Ideologias de diferenciação linguística interpretam o fenômeno sociolinguístico dentro de sua visão através de três processos semióticos que chamamos iconização, recursividade e apagamento. (IRVINE, 2001, p. 33).

Vejamos como Irvine define os processos semióticos por ela mencionados:

[i] Iconização é um processo semiótico que transforma a relação sígnica entre os traços linguísticos [ou variedades] e as imagens sociais às quais estão ligados. Diferenças linguísticas parecem ser representações icônicas dos contrastes sociais que elas indicam - como se um traço linguístico representasse ou demonstrasse, de certa maneira, a natureza ou essência inerente de um grupo social. A representação ideológica - ela própria um signo - opera em termos de imagens; elege qualidades supostamente compartilhadas pela imagem social e pelos traços linguísticos (ou melhor, uma imagem de tais traços), juntando essas imagens. […]

\footnotetext{
2 As citações de Irvine (2001) e dos demais textos que fazem parte de Eckert e Rickford (2001) [Style and Sociolinguistic Variation. Cambridge: Cambridge University Press, 2001], foram feitas a partir da tradução brasileira dessa obra [no prelo], coordenada por Anna Christina Bentes. Nos demais casos, as traduções de citações de textos em inglês são de nossa responsabilidade.
} 
[ii] Recursividade envolve a projeção de uma oposição, saliente em um nível da relação, sobre outro nível. É o processo pelo qual distinções significativas (entre grupos, entre variedades linguísticas, etc.) são reproduzidas dentro de cada lado de uma dicotomia ou divisão, criando subcategorias e subvariedades; ou, ao contrário, pelo qual oposições intragrupais podem ser projetadas externamente sobre relações intergrupais, criando supercategorias que incluem ambos os lados, mas os opõem a alguma outra coisa. […]

[iii] Apagamento, por sua vez, é o processo pelo qual uma ideologia simplifica o campo sociolinguístico. Atendendo a uma dimensão da distintividade, ela ignora o outro, colocando assim alguns fenômenos sociolinguísticos (ou pessoas, ou atividades) na invisibilidade. Assim, por exemplo, um grupo social ou uma língua podem ser imaginados como homogêneos, sua variação interna sendo desconsiderada ou justificada ${ }^{3}$. (IRVINE, 2001, p. 33-34, grifos nossos).

Irvine (2001, p. 37) percebeu que no Wolof "os contrastes linguísticos que diferenciam os estilos não são arbitrários, ao contrário, são motivados por uma ideologia da língua”. É um exemplo do que a autora chama de iconização.

Conforme já apontado anteriormente, uma noção bastante importante nas discussões sobre estilo em sociolinguística é registro. Recorremos aqui às ideias de Agha (2005, 2007), que considera os registros não como fatos estáticos sobre a linguagem, mas modelos reflexivos do uso da língua (AGHA, 2005, p. 38).

Para Agha (2005, p. 38), além de serem "modelos reflexivos do uso da língua que são disseminados ao longo de trajetórias identificáveis no espaço social por meio de processos comunicativos”, registros também são "formações históricas que podem ser apreendidas em processos grupais de valorização e contra-valorização, exibindo mudanças ao longo do tempo tanto na forma como no valor” (AGHA, 2007, p. 148).

Agha busca entender um dos aspectos do processo social reflexivo envolvido na constituição dos registros: as várias formas de revaloração, retipificação e de mudança que os estilos sofrem no curso de qualquer processo social de disseminação. Também busca entender o papel dos processos de voicing em relação aos registros. Nesse sentido o autor argumenta que

os encontros com os registros não são meramente encontros com vozes (ou figuras e personae caracterizáveis) mas encontros nos quais os indivíduos estabelecem formas de footing e alinhamento com vozes marcadas pelo discurso e assim com tipos sociais de pessoas, reais ou imaginadas, cujas vozes são tomadas como existentes. (AGHA, 2005, p. 38).

Tendo em vista a relação que há entre voz e registro, Agha remete à distinção estabelecida por Bakhtin, para quem vozes são "modos pelos quais enunciados indiciam [index] personae falantes tipificáveis" (AGHA, 2005, p. 39). E registros "indicam atributos sociais do falante, tais como gênero, classe, casta e profissão" (ibidem). Assim, "contrastes de vozes envolvem figuras de personalidade [personhood] que são justapostas dentro de estruturas de contextualização compostas por vários tipos de signos linguísticos (sejam eles escritos ou orais) e não linguísticos" (AGHA, 2005, p. 39).

Agha (2005, p. 39) afirma ainda que, em termos gerais, o que Bakhtin chama de vozes sociais são figuras discursivas que permitem caracterização por meio de um metadiscurso dos tipos sociais de atributos de uma (ou mais de uma) persona. E é nesse conjunto que reside uma subclasse particularmente interessante, a classe das vozes sociais ligadas aos registros, às quais Agha chama de "vozes socialmente reconhecidas" (enregistered voices). Elas têm um personagem (character) "social" em dois sentidos diferentes: primeiro, as formas do registro são indexadores (indexicals) sociais no sentido de que elas indicam personae sociais estereotípicas (por exemplo, o falante é um homem, de classe baixa, um médico, um aristocrata, etc.), que podem também ser figurativizadas para produzir personae híbridas de vários tipos. Assim, todo registro tem um alcance social (social range), uma cadeia de figuras performatizáveis por meio de seu uso.

Registros são formações sociais no sentido de que alguns usuários da língua, mas não outros, são socializados no seu uso e formação. Assim todo registro também tem um domínio social, um grupo de pessoas familiarizadas com - e minimamente capazes de reconhecer - as figuras performatizáveis por meio de seu uso.

3 Embora a autora tenha listado três processos semióticos, ela observa em nota que, em certo sentido, eles são todos aspectos de um mesmo processo semiótico, a iconização. 
O fato de os registros serem usados por pessoas sociais e indiciarem personae introduz uma reflexividade inerente à vida social dos registros. Os encontros de registros não são apenas encontros com figuras caracterizáveis indiciadas pela maneira de falar, mas dizem respeito a eventos nos quais os interlocutores estabelecem algum footing ou alinhamento com figuras performatizadas por meio da fala, e desse modo uns com os outros.

E essa reflexividade em torno dos registros é tomada sob outro ponto de vista por Coupland, embora sua visão não seja incompatível com as postulações de Agha. Na verdade, Coupland (2001, 2007) trabalha com a noção de estilização, conceito originalmente associado ao criticismo literário e cultural de Mikhail Bakhtin. Para Bakhtin, estilização tem tanto significados específicos quanto gerais. Ela é "uma imagem artística da linguagem do outro" (BAKHTIN, 1981, p. 262). Mas é também uma qualidade geral do uso linguístico. Bakhtin afirma que "o homem moderno já não proclama, nem declama" pelo contrário, ele "fala com restrições" (BAKHTIN, 2000, p. 371); ele estiliza o gênero proclamatório nobres - sacerdotes, profetas, pregadores, juízes, patriarcas e assim por diante (cf. BAKHTIN 2000, p. 371). Por essa razão, segundo Coupland (2007), a estilização bakhtiniana não se caracteriza apenas como um efeito "artístico", ela é, na verdade, uma forma subversiva de um enunciado onde estão presentes múltiplas vozes, uma forma que desacredita os discursos hegemônicos, monológicos pela apropriação de vozes dos poderosos, e as reorganiza para novos objetivos. Para Bakhtin, a estilização é uma instância central do dictum que encontramos anteriormente:

nossa fala, isto é, nossos enunciados [...], estão repletos de palavras dos outros, caracterizadas, também em graus variáveis, por um emprego consciente e decalcado. As palavras dos outros introduzem sua própria expressividade, seu tom valorativo, que assimilamos, reestruturamos, modificamos. (BAKHTIN, 2000, p. 314 , grifo do autor).

Coupland (2007, p. 146) defende que uma característica da maior parte da (senão de toda a) prática de estilização é a noção de performance. Coupland lembra também que umas das ideias fundantes da sociolinguística foi mudar a concepção de que a língua em uso poderia ser deixada de lado por ser uma "mera performance", ainda que essa noção implicasse uso cotidiano da língua ou comportamento efetivo. Coupland (2007) reconhece o papel agentivo dos falantes na construção dos significados no modo como eles contextualizam a variação. Além disso, quando reconhecemos que o ato de falar envolve um grau de consciência metalinguística, parece correto pensar em falantes performatizando discursos.

Ao propor tais ideias, o que Coupland está sugerindo é que os falantes projetam sua fala, conscientes - em algum nível de consciência e com algum nível de controle autônomo - das possibilidades alternativas e dos resultados prováveis de sua prática discursiva. É por isso que se pode afirmar que os falantes performatizam identidades, projetando a si mesmos ou a outros, quando eles têm alguma consciência de como as personae relevantes construídas são provavelmente percebidas por meio de sua projeção. No livro Capão Pecado (objeto de análise neste artigo), por exemplo, há projeções de várias personae (do autor/narrador, das personagens, dos destinatários), sinalizadas, em certa medida, por suas manifestações linguísticas e pelos valores sociais que defendem.

Outra questão mencionada por Coupland - e relevante para nossas análises - é que a consideração metodológica de que as variantes têm similitude referencial tem obscurecido o potencial de as variantes de estilo dialetal serem ideologicamente não equivalentes. "As variantes de estilo dialetal podem ser modos alternativos de alcançar o mesmo referente, mas isso não acarreta que sejam formas alternativas de 'dizer' ou 'querer dizer' 'a mesma coisa'. (COUPLAND, 2001, p. 190). Coupland (2001, p. 191) acrescenta ainda que "estilos dialetais se tornam significativos para nossas identidades pessoais e nossos relacionamentos através das formas pelas quais eles nos remetem a outros processos simbólicos no discurso".

Coupland (2001, p. 191) chama a atenção para o fato de que, numa orientação distribucional, que utiliza as mesmas ferramentas orientacionais e epistemológicas que norteiam a análise da estratificação das comunidades (predominante nos estudos do estilo até então) "não há lugar para propósitos comunicativos". $\mathrm{E}$ isso porque, segundo o autor, as categorias apropriadas para pesquisar o comportamento conjunto dos indivíduos nem sempre são apropriadas para explicar a variação estilística que ocorre na interação dos indivíduos dentro de seus próprios espaços, tempos e contextos relacionais.

Coupland aponta, assim, o caráter reducionista das pesquisas realizadas com base no paradigma laboviano sobre o estilo, já que essas abordagens excluem qualquer interpretação local dos processos intra e 
interpessoais, que são domínio do estilo, e afirma que, se o estilo deve ser entendido como motivado intra e interpessoalmente, não podemos teorizar o estilo fora do domínio da ação social e discursiva (COUPLAND, 2001, p. 192-193). Consequência dessa ideia é a colocação em cena da noção de contexto em sociolinguística e a necessidade de se levar em conta a organização social dos sentidos através dos discursos interativos.

Seguindo essas indicações das abordagens teóricas mencionadas acima, e que se situam no que Eckert (2005) chamou de "terceira onda" nos estudos sociolinguísticos, buscamos analisar alguns aspectos lexicais de Capão Pecado, de Ferréz, relacionados à variação sociolinguística, especialmente ligados à identidade dos manos - sujeitos de diferentes faixas etárias e pertencentes a diferentes estratos sociais. Saliente-se que as noções e as abordagens dos vários autores aqui apresentados convergem no sentido de que as variáveis (linguísticas e não linguísticas) exercem a função de sinalizarem significados sociais e não apenas variação estilística no sentido que Labov dava a esse termo.

\section{SOBRE FERRÉZ E O CAPÃO PECADO}

\section{Ferréz}

Ferréz é o pseudônimo adotado por Reginaldo Ferreira da Silva, que o escolheu para fazer referência a dois líderes populares: Virgulino Ferreira da Silva, o Lampião, (daí o "Ferre"), e Zumbi dos Palmares (o "Z" acrescentado). Reginaldo, ou melhor, Ferréz, nasceu em 29 de dezembro de 1975, no bairro do Valo Velho, distrito do Capão Redondo, Zona Sul de São Paulo. O escritor se declara um "produto do meio brasileiro" que optou por se definir como negro por considerar honroso defender "o lado mais prejudicado na história" (NASCIMENTO, 2006, p. 104).

Ferréz estreou como escritor em 1997 com o livro de poesia concreta Fortaleza da desilusão, patrocinado pela empresa onde trabalhava. Mas o livro não teve repercussão na imprensa, tampouco atraiu grande público à sessão de autógrafos realizada na Biblioteca Pública de Santo Amaro. Em 1999, juntamente com um grupo de moradores da Zona Sul paulistana, fundou o autodenominado "movimento cultural 1daSul", cujo objetivo era desenvolver atividades culturais e sociais, e desenvolver projetos de criação de bibliotecas comunitárias. 1daSul passou a ser também o nome da grife e da loja que Ferréz criou no bairro do Capão Redondo e que comercializa itens diversos relacionados ao estilo hip hop (roupas, bonés, chaveiros, livros, discos, etc.).

Já Capão Pecado, lançado em 2000, alcançou grande sucesso e em 2005, com duas edições esgotadas, passou a ser editado pela Editora Objetiva, que também publicou outras obras do autor, tais como Manual Prático do Ódio (2003), conjunto de contos, Amanhecer Esmeralda (2005 - infantil) e Ninguém é inocente em São Paulo (2006). Pela "Selo Povo" 5, coleção de livros de bolso criada pelo próprio Ferréz, lançou Cronista de um tempo ruim (2009).

\section{Sobre a consciência do sujeito acerca do estilo a ser usado}

Embora não seja o foco deste trabalho, a entrevista "Processo Criativo do Livro Manual Prático do Ódio6", disponível na internet, fornece informações importantes sobre o grau de consciência do autor acerca da necessidade de estilizar a fala das personagens em função do ambiente onde elas circulam e dos interlocutores com os quais interagem em seus livros:

\footnotetext{
4 Referimo-nos ao que Eckert (2005) chamou de "três ondas” da prática analítica nos estudos da variação linguística. A “primeira onda” inclui os estudos fundadores do campo iniciados por Labov (em 1966) e se caracterizam por buscar estabelecer correlações entre as variáveis linguísticas (nos grandes centros urbanos) e as categorias primárias de classe socieconômica, gênero e idade, fornecendo, assim, elementos para um quadro geral da variação. O estilo, na "primeira onda", é concebido como a variação em função da atenção que o sujeito dá à sua fala, de acordo com o prestígio/estigma. Já a "segunda onda" inclui os estudos etnográficos focados na variação de populações mais localmente definidas, buscando desenvolver um quadro mais local, em que as variáveis sejam percebidas como indexadores de categorias localmente definidas. Nesse caso, o estilo é visto como um ato de afiliação do falante em relação à comunidade de fala. A "terceira onda" (na qual se situa o presente artigo) tem como foco as variáveis que funcionam como indexadores de posturas e de significados construídos socialmente. Estilo, nesse caso, é visto como construção de persona, a partir dos traços linguísticos.

5 "Selo Povo" é uma coleção de livros de bolso, "escritos por e para mãos operárias, rebeldes, marginais, periféricas", descreve Ferréz, que custam o "preço de uma cerveja e meia: 5 reais para o público final e 4 reais para quem se interessar pelo trabalho de distribuição" (Informação disponível em: <http://selopovo.blogspot.com/>. Acesso em: 26 jul. 2011).

6 Entrevista na qual Ferréz fala sobre o método de escrita de seu livro Manual Prático do Ódio”. [Vídeo disponível em: <http://www.youtube.com/watch?v=2Yjo9qFQXBU\&NR=1>. Acesso em: 13 jun. 2011.
} 


\begin{abstract}
... separo os relacionamentos e vou separando os personagens, aí eu separo os personagens por núcleos também, entendeu? Eu vou separando os núcleos dos personagens... tem um outro papel aqui [mexendo em várias folhas manuscritas que estão amontoados sobre sua mesa de trabalho] que é a separação dos personagens [...] aí eu vou separando também as fala... né... são... eu vou picotando as falas... por que? porque cada personagem tem um tipo de fala diferente... então, por exemplo, se você vê aqui ó ... bar do Marrocos... então aqui o tipo de linguagem do bar do Marrocos é um tipo de linguagem diferente do neguinho [inaudível] na casa dele porque na casa dele é claro a família puxa mais pra uma linguagem normal e no bar é uma linguagem mais despojada (2'34-2'47). ${ }^{7}$
\end{abstract}

Em outra entrevista ${ }^{8}$, concedida ao programa "Fortalecendo a Corrente", Ferréz também demonstra consciência da relação entre a linguagem usada e a identidade social dos interlocutores tanto do programa do qual está participando quanto do grupo com o qual ele se identifica e que constitui personagens de sua obra:

... é uma satisfação tá aqui no programa, um programa feito pelo povo da gente né mano que é uma coisa difícil hoje pela imprensa né geralmente que as pessoas que fazem a FAAP, que fazem as USP da vida é os que tem os programa e não falam a linguagem da gente então é uma honra poder tá aqui poder falar dos assuntos que têm a ver com o nosso povo (1'20 - 1'37).

Com relação à consciência de a literatura "pertencer" a uma elite, assim se manifesta Ferréz na mesma entrevista (segunda parte) ${ }^{9}$ :

... quando eu sentei com essas pessoas [pessoas ricas] que a gente ... nos lançamentos ... literatura é muito elitizada... na literatura a gente convive com gente rica o tempo todo certo?.... (4'29-4'38).

Essas transcrições de falas de Ferréz, apesar de não serem o objeto de análise em neste artigo, corroboram as ideias de Irvine (2001) - de que os sujeitos têm consciência do registro a ser usado -, e de Agha (2005), segundo a qual os sujeitos "alinham" seu discurso de forma a performatizar uma dada personae social reconhecida e reconhecível por meio de suas manifestações linguísticas.

\title{
Sobre o livro Capão Pecado
}

Capão Pecado, trabalho mais conhecido de Ferréz, é o segundo livro do autor, publicado em 2000. Diferentemente de Fortaleza da desilusão, Capão Pecado é um sucesso e colocou Ferréz entre os grandes nomes da chamada literatura marginal. O título do livro é uma referência ao bairro Capão Redondo, onde se passam as histórias nele narradas. O mote do livro é a vida sofrida dos moradores da periferia, quase sempre submetidos a situações de discriminação e exclusão social.

O livro é dividido em cinco partes, sendo que a primeira corresponde aos capítulos um a quatro; a segunda, aos capítulos cinco a nove; a terceira, aos capítulos dez a quinze; a quarta, aos capítulos dezesseis a vinte; e a quinta e última parte do livro corresponde aos capítulos vinte e um a vinte e três. Os capítulos são pequenos - média de quatro ou cinco páginas - com uma narrativa rápida e direta, em que se destaca a voz das personagens, quase sempre amigos de Rael - personagem principal do livro e em torno do qual se desenrolam os fatos - ou com ele ligados, seja por relações de trabalho ou afetivas.

\section{UM OLHAR QUANTITATIVO SOBRE ALGUMAS OCORRÊNCIAS LEXICAIS EM CAPÃO PECADO}

O objetivo deste item é apresentar um pequeno levantamento de alguns usos lexicais em Capão Pecado, relacionando esses usos à forma como os registros linguísticos são vistos e manuseados no livro. Para isso, dividimos a apresentação dos dados em duas partes: na primeira, fazemos alguns comentários gerais sobre a relação entre o léxico e os registros usados no discurso do autor e das personagens. Na segunda parte do item, apresentamos uma amostra do tratamento estatístico que julgamos adequado para tratar de questões

\footnotetext{
7 Os números entre parênteses nas transcrições das entrevistas de Ferréz indicam o intervalo (minutos e segundos) onde aparece o texto transcrito neste artigo.

8 Entrevista concedida por Ferrez ao Programa Fortalecendo a Corrente - Parte 1, em 13 de fevereiro de 2009. Disponível em: <http://www.youtube.com/watch?v=3XShqw9LN2o\&NR=1>. Acesso em: 13 jun. 2011.

9 http://www.youtube.com/watch?v=sJoWhgeEOSk\&feature=related
} 
relativas às variáveis de ordem semântico-lexical usadas pelas várias “vozes" presentes no texto: trata-se de um levantamento das ocorrências dos lexemas mano/amigo/cara/truta/maluco para se fazer referência à terceira e à segunda pessoa do discurso. Esse fenômeno foi escolhido por julgarmos que, por meio dele, pode-se vislumbrar o movimento estilístico de construção e afirmação da identidade dos chamados manos.

Embora haja um levantamento estatístico de algumas das formas analisadas, não pretendemos elaborar uma análise quantitativa exaustiva do vocabulário: nossa intenção é mostrar, a partir do número de certas ocorrências, algumas tendências que estão relacionadas à percepção da variação por parte do autor e ao modo como ele manuseia os diferentes registros linguísticos [no sentido que Irvine (2001) atribui a esse termo] percebidos em sua comunidade de fala. Nossa proposta, então, para a análise dos dados é mais qualitativa e menos quantitativa.

A linguagem utilizada no livro - e aqui reside nosso interesse direto - ousamos afirmar que traduz a maneira por meio da qual os moradores jovens da periferia paulistana (os manos) se comunicam nas interações cotidianas. Mais ainda, tentaremos demonstrar, por meio de elementos linguísticos, como o autor do livro (especialmente na voz do narrador) busca traduzir não só o modo de falar dos manos, mas também o modo como eles veem os embates ideológicos travados na sociedade urbana onde vivem e por que transitam diariamente. E, diante desse embate ideológico mostrado em Capão Pecado, o narrador-autor - ousamos novamente - se posiciona como morador da periferia e, mais ainda, como uma voz pela qual o homem da periferia - das "quebradas" - não só expõe seus anseios pessoais, mas também se situa em sociedade, identificando-se com determinado grupo e, em consequência dessa identificação, opondo-se a outros grupos, que, embora não mencionados nominalmente, são condensados sob o rótulo de playboys.

Assim, o uso da forma playboy (e suas variantes playba, boy) indica um conflito social ao qual estão submetidos os moradores da periferia (o que inclui o próprio autor de Capão Pecado), que demanda deles a contínua construção de uma identidade local linguisticamente marcada. Essa busca de afirmação da identidade social local pode ser percebida também pela rejeição de certos comportamentos associados ao grupo colocado em oposição aos manos, conforme pode ser observado nos dois exemplos a seguir.

Exemplo (1)

[Rael] chegou e não gostou nada quando a mãe lhe disse que ele teria que retirar seu pagamento lá no mercado do seu Halim.

- Ah! mãe, você sabe que eu não gosto de trocar ideia com esses playboys, e ainda mais receber. [ [...]

Chegando ao mercado de seu Halim, o pão-duro já o havia visto de longe e já estava contando o dinheiro para lhe dar. Rael se aproximou e Halim nem o cumprimentou, só entregou o dinheiro e disse que o serviço de sua mãe estava lhe custando muito dinheiro. Rael não respondeu nada, só guardou o dinheiro no bolso, disse obrigado e se retirou. Mas Halim notou algo em seu rosto, algo estranho, talvez por um momento Hallim tenha visto nos olhos daquele menino periférico um sentimento de ódio puro e tenha sentido por algum momento que um dia o jogo iria virar. (p. 23-24) ${ }^{10}$.

Exemplo (2)

Zeca buscou a cerveja e continuou bebendo, mas de repente lembrou de uma reportagem que tinha lido naquela manhã, a matéria dizia que São Paulo era uma das cidades mais badaladas do mundo, uma das únicas que funcionam 24 horas, na matéria se destacavam casas noturnas, restaurantes e todos os tipos de comida que eram encontrados nas noites. Zeca comparou tudo aquilo que os playboys curtiam e o que ele tinha ali em sua frente, resolveu para de pensar nisso, andou alguns metros e foi comer um churrasquinho na barraca da dona Filó. (p. 30) [Narrador $]$.

Exemplo (3)

Marquinhos deu o dinheiro e Mixaria soltou um grande sorriso, finalmente poderia pôr seu carro num lugar seguro e, o melhor de tudo, entraria pelo clube, e não teria que passar pela lama, nem pular os arames da divisa, seu sentimento de satisfação era dividido com todos ali dentro, que se sentiram importantes e até fingiram estar falando ao celular, menos Burgos, que odiava tanto os playboys que não tinha coragem nem de imitá-los. (p. 50). [Narrador $]$.

10 Todos os exemplos são extraídos do livro analisado: Capão Pecado (FERRÉZ, 2005), razão pela qual são indicados apenas os números das páginas citadas e não a obra. 
O discurso do narrador, a nosso ver, se constrói a partir de uma oposição social não só explicitamente quando fala do "outro", mas também por meio de expressões linguísticas - especialmente as referenciais quando o narrador-autor faz referência aos seus pares. Isso pode ser constatado com uma rápida olhada no léxico utilizado no livro (e que será objeto de discussão mais detalhada na segunda parte deste item). Notese que, no uso de determinadas expressões (mano, truta, maluco, mala, sangue no olho, quebrada, etc.) e no não uso de outras (bandido, assassino, assassinato, roubo, etc.), é que se constrói o significado social e a situação das vozes que se manifestam como pertencentes a um ou outro grupo social. Nota-se ainda que os lexemas quebrada, periferia e mesmo favela são as formas preferencialmente usadas pelo narrador e pelas personagens para se referirem aos bairros periféricos onde se desenrolam os fatos narrados (a palavra "bairro" praticamente não aparece no livro).

Digno de nota também é o fato de que as palavras "assassino" (em sentido estritamente referencial, ou como predicado atribuído a alguma das personagens), "assassinato", "bandido", "criminoso", praticamente não ocorrem em Capão Pecado, embora sejam narradas várias cenas de assassinato (violentos na maioria das vezes) e outros crimes envolvendo não só morte como também tráfico de drogas e armas (em tempo: as palavras "cocaína", "crack" também não ocorrem, sendo geralmente substituídas por "farinha” e "pedra", respectivamente). Já a palavra "policial”, embora seja usada, geralmente alterna-se com "gambé”, mesmo na voz do narrador, o que permite pensar que a voz narradora se constitui a partir do ponto de vista dos manos. Vejamos alguns exemplos das ocorrências sobre as quais estamos falando.

\section{Exemplo (4)}

Combinaram de ir ao baile da News Black Chic, lá no pátio da escola José Olímpio; o som da equipe era muito bom e vinha gente lá do Valo Velho, Piraporinha, Jardim Ingá, Pirajussara, Morro do S, Parque Regina, Parque Arariba, São Luís, Buraco do Sapo, Parque Fernanda e de várias quebradas, pois os bailes e rolês noturnos eram cada vez mais raros na periferia. (p. 23) [Narrador].

[...] o respeito na quebrada sempre prevalece para aqueles que sabem se impor na humildade, e foi isso que Capachão procurou fazer desde o primeiro dia em que tinha mudado para Jangadeiro. (p.28) [Narrador].

Exemplo (5)

Cebola avisou que o palco já estava armado e que Burgos nunca saía na correria à toa, alguma coisa tava pegando pro lado do Will, e que desconfiava que haviam sido os manos da Paraisópolis que tinham contratado o Burgos pra fazer o serviço; afinal as bocas não podem se dar ao luxo de ficar no prejuízo, porque os negócios despencam: é só um nóia saber que tal mano comprou na boca, não pagou, e nada aconteceu, que tá feito o boato que os chefes da boca não tão com nada. $O$ respeito tem que prevalecer. Rael concordou com a tese do amigo e ficou mais preocupado ainda porque sabia que Burgos era sangue no olho e que se ele tava na treta, nada mais poderia ser feito pelo Will. (p. 32-33) [Narrador].

Exemplo (6)

Os policiais adentraram a favela e ordenaram mão na cabeça. Matcherros estava com os cadernos na mão esquerda, um dos policiais engatilhou a arma e disse que se alguém corresse levaria bala. Bateram geral, perguntaram se era só ideia, se não estava rolando um baseado; China disse que era só ideia, um dos policiais lhe deu um tapa na cara, ele se injuriou e jogou a trouxinha de maconha no policial. O capitão desceu do carro, pegou a trouxinha e perguntou se ele só tinha aquela. China disse que sim, o policial a pôs no bolso e começaram a bater geral em duas minas que desciam da Cohab. A morena mais gostosa teve as mãos do policial apalpando suas nádegas, suas pernas, seus seios firmes; o gambé disse baixinho em seu ouvido:

- Acho que já te vi lá na Aurora, hein, sua vadia?!

A morena nada falou, mas seus olhos se encheram de lágrimas.

Ao fundo Matcherros notou um gambé com o cassetete na mão, e mesmo com a cabeça baixa percebeu ser seu amigo capachão.

A polícia subiu o morro, pois um boteco lá em cima chamava a atenção pelo alto volume do som. As frases dos grupos de rap deixaram irados os gambés, que chegaram botando pra quebrar no bar do seu Tinho Doido [...]. O som, antes de ser interrompido por motivo de perfuração à bala, bradou o último verso: "Não confio na polícia, raça do caralho".

O emprego desses itens nos exemplos 4, 5 e 6 parece corroborar nossa tese de que a voz do autor-narrador, ao se manifestar, não o faz como alguém de fora do grupo que protagoniza os fatos - e que, portanto, traduziria seu ponto de vista por meio de expressões com conotação avaliativa diferente daquela que de fato 
ocorre no livro -, mas o faz como um membro daquele grupo, cuja voz se coloca do lado dos marginalizados, ainda que nem sempre concorde com o modo de agir de alguns membros do grupo.

Capão Pecado constitui-se, assim, como uma afirmação - por meio de um objeto cultural altamente elaborado, como é o caso do livro em nossa sociedade - da identidade do morador da periferia paulistana - o mano - a partir da sua visão e não a partir da visão de alguém de fora da periferia.

Os estilos linguísticos construídos em Capão Pecado se constituem a partir da manipulação de diversos recursos, em vários níveis linguísticos (o discursivo, o textual, o lexical, o sintático e o fonológico). No entanto, por questão de espaço, serão tratados neste artigo apenas os recursos de ordem lexical. Nesse sentido, passamos agora a uma breve análise de algumas ocorrências de itens lexicais, que dizem respeito às manifestações das "vozes" presentes no texto: trata-se da alternância dos lexemas mano/amigo/cara/truta/maluco para se fazer referência à segunda e à terceira pessoa do discurso.

Embora a referência à segunda e terceira pessoa do discurso possa ser feita por meio de pronomes e nomes próprios, não analisamos essas ocorrências porque acreditamos que a variação mais relevante para nossos objetivos é aquela que ocorre no uso do substantivo núcleo do sintagma nominal (SN) em análise, conforme indicaremos melhor a seguir.

Nesse sentido, quantificamos ${ }^{11}$ as ocorrências de alguns itens que julgamos pertinentes para a caracterização da identidade dos manos. São eles os lexemas mano, cara, amigo, truta e maluco. O resultado dessa quantificação pode ser visto na Tabela 1, na qual, na coluna "Narrador (3P)", estão indicadas as ocorrências em que o narrador usa cada uma das palavras para fazer referência à terceira pessoa do discurso. Na coluna " $3 \mathrm{P}$ - Terceira Pessoa" aparecem as quantidades de ocorrências em que as personagens usam cada uma das palavras para fazerem referência à terceira pessoa do discurso. Na coluna "Marcador Conversacional" aparecem as quantidades de ocorrências em que as personagens usam cada uma das palavras para fazer referência à segunda pessoa, e que funcionam textualmente como marcador conversacional e/ou marcador discursivo ${ }^{12}$. Seguem no Quadro 1 exemplos de cada um desses tipos de ocorrências.

Tabela 1 - Ocorrências dos vocábulos mano, cara, amigo, truta, maluco

\begin{tabular}{|c|c|c|c|c|c|c|c|c|}
\hline \multirow{3}{*}{$\begin{array}{l}\text { Item lexical } \\
\text { mano }\end{array}$} & \multirow{2}{*}{\multicolumn{2}{|c|}{ Narrador (3P) }} & \multicolumn{4}{|c|}{ Personagens } & \multirow{2}{*}{\multicolumn{2}{|c|}{$\begin{array}{c}\text { Total de } \\
\text { ocorrências de } \\
\text { cada item }\end{array}$}} \\
\hline & & & \multicolumn{2}{|c|}{ 3P - Terceira Pessoa } & \multicolumn{2}{|c|}{ Marcador conversacional/Vocativo } & & \\
\hline & 11 & $13 \%$ & 17 & $21 \%$ & 54 & $66 \%$ & 82 & $100 \%$ \\
\hline cara & 6 & $32 \%$ & 9 & $47 \%$ & 4 & $21 \%$ & 19 & $100 \%$ \\
\hline amigo & 50 & $96 \%$ & 1 & $2 \%$ & 1 & $2 \%$ & 52 & $100 \%$ \\
\hline truta & 1 & $9 \%$ & 2 & $18 \%$ & 8 & $73 \%$ & 11 & $100 \%$ \\
\hline maluco & 5 & $25 \%$ & 10 & $50 \%$ & 5 & $25 \%$ & 20 & $100 \%$ \\
\hline Total & 73 & - & 39 & - & 72 & - & & \\
\hline
\end{tabular}

\footnotetext{
11 Tendo em vista que nossas análises são mais qualitativas, e, portanto, apenas indicativas de tendências, fizemos um levantamento (manual) do número de ocorrências (dos vocábulos mano, cara, amigo, truta, maluco) de doze (dos vinte e três) capítulos de Capão Pecado. Foram considerados os capítulos de um a três e de seis a quatorze. Dois foram os critérios de escolha desses capítulos: o primeiro refere-se à ocorrência de pelo menos dois vocábulos analisados; e o segundo refere-se à presença tanto de trechos narrativos quanto de diálogos entre as personagens.

12 Risso et al. (2006, p. 404) fazem uma distinção teórica entre os conceitos de marcador discursivo e marcador conversacional, e optam pelo uso da primeira expressão por julgarem que ela é mais adequada e mais abrangente, já que pode fazer referência tanto às ocorrências escritas quanto às ocorrências da modalidade oral. Já a segunda expressão, marcador conversacional, segundo Risso et al. (2006), corre o risco de sugerir um comprometimento exclusivo com a língua falada e com um gênero específico desta: a conversação. Apesar de cientes dessas questões teóricoterminológicas, consideramos de forma bastante abrangente a categoria que chamamos "marcador conversacional/vocativo", pois, como poderá ser observado nos exemplos do Quadro 1, ela abarca ocorrências que funcionam mais como vocativos. E como vocativos têm função interacional, no sentido de que eles marcam a presença do interlocutor na interação e assinalam a quem se destina a declaração, nesse ponto (da função interacional que cumprem) eles se assemelham a outros elementos da classe dos chamados "marcadores conversacionais", podendo ser nela incluídos.
} 
Quadro 1 - Exemplos dos usos dos vocábulos mano, cara, amigo, truta, maluco

\begin{tabular}{|c|c|c|c|}
\hline \multirow{2}{*}{$\begin{array}{l}\text { Item } \\
\text { lexical }\end{array}$} & \multirow[b]{2}{*}{ Narrador(3P) } & \multicolumn{2}{|c|}{ Personagens } \\
\hline & & 3P - Terceira Pessoa & Marcador Conversacional/Vocativo \\
\hline mano & $\begin{array}{l}\text { Na Pequena roda em torno do poste } \\
\text { estavam Matcherros, Panetone, } \\
\text { Amaral, Cebola, Alaor e Amarelos. } \\
\text { Rael chegou cumprimentando os } \\
\text { manos, e já entrou na conversa logo } \\
\text { de cara, como era de seu feitio. (p. } 25)\end{array}$ & $\begin{array}{l}\text { - O que pegava lá, Burgos, é que o som } \\
\text { da equipe tinha uma puta qualidade, } \\
\text { aqueles manos da Thalentos são foda, } \\
\text { além do equipamento eles agitam o } \\
\text { pessoal pra caramba. (p. 29) }\end{array}$ & $\begin{array}{l}\text { - Não Burgos, eu tô a pampa. Porra, o } \\
\text { bagulho tá cheio hoje, hein, mano! } \\
\text { - É! O bar do Polícia é o point agora, cê } \\
\text { tá ligado? Também, o lava-rápido lá } \\
\text { perto da igreja fechou; lá dava umas } 2 \\
\text { mil pessoas, mano. (p. } 29 \text { ) }\end{array}$ \\
\hline cara & $\begin{array}{l}\text { Como uma coisa tão linda como } \\
\text { aquela que estava em sua frente se } \\
\text { apaixonara por um cara daquele } \\
\text { jeito? (p. } 48) .\end{array}$ & $\begin{array}{l}\text { - [...] Tenho dois filho pra criar, agora o } \\
\text { cara leva meu lucro [...] (p. 63) } \\
\text { - É, mas ele perdeu toda a razão quando } \\
\text { fugiu e abandonou a moto lá. Também; e } \\
\text { o medo de ter que pegar cana por causa } \\
\text { da mina do cara... (p. } 72)\end{array}$ & $\begin{array}{l}\text { - É, cara, eu num sei não. Pelo que ela } \\
\text { me fala, deve gostar muito de você. (p. } \\
56 \text { ) } \\
\text { - Eu sei, cara, mas eu não queria mais } \\
\text { ficar amarrado com ninguém (p.56) }\end{array}$ \\
\hline amigo & $\begin{array}{l}\text { Rael estava conversando com } \\
\text { Chapolim, Paula o chamou para ir } \\
\text { embora. Ele se despediu do novo } \\
\text { amigo e foi com ela. (p. 53) }\end{array}$ & $\begin{array}{l}\text { - Olha, Paula, eu também não sei o que } \\
\text { aconteceu, só sei que pra mim foi bom, } \\
\text { mas o Matcherros é um ótimo amigo e } \\
\text { estou me sentindo culpado. (p. } 73 \text { ) }\end{array}$ & $\begin{array}{l}\text { - [...] eu não posso fazer nada }[\ldots] \\
\text { - Você pode fazer sim, amigo. Fica de } \\
\text { olho lá na firma, se ela se interessar por } \\
\text { alguém }[\ldots], \text { você me conta (p. } 56 \text { ) }\end{array}$ \\
\hline truta & $\begin{array}{l}\text { Chegou a cumprimentar os trutas, } \\
\text { Cebola foi lhe perguntando como } \\
\text { tinha sido o dia de serviço, Rael } \\
\text { respondeu que tinha sido como os } \\
\text { demais dias, sem novidade. (p. } 77 \text { ) }\end{array}$ & $\begin{array}{l}-[\ldots] \text { E o pior é que, se você analisar os } \\
\text { fatos, vai notar que de todos os trutas } \\
\text { só um ou dois patrícios tão querendo } \\
\text { algo. (p. 92) }\end{array}$ & $\begin{array}{l}\text { - E aí, manos!Que saudade, por onde } \\
\text { vocês tavam, hein? } \\
\text { - Rael, meu truta! Nós tava em } \\
\text { Paraisópolis […] (p. } 31 \text { ) } \\
\text { - Pois é, truta, ele tava indo lá direto, } \\
\text { tava pegando mó consideração, } \\
\text { desconversou e nunca mais voltou lá! } \\
\text { (p. 76). }\end{array}$ \\
\hline maluco & $\begin{array}{l}\text { A fila estava andando, mas logo se } \\
\text { desmanchou quando um cara saiu lá } \\
\text { de dentro reclamando que a mãe do } \\
\text { maluco havia retirado o corpo e o } \\
\text { pusera na cama. (p. } 52 \text { ) }\end{array}$ & $\begin{array}{l}\text { - Então! E o maluco num qué ter } \\
\text { companhia boa? Deixa ele choque, cada } \\
\text { cabeça seu guia. (p. } 76 \text { ) }\end{array}$ & $\begin{array}{l}\text { - Que porra de fita, maluco, tá } \\
\text { entrando numas? (p. 49) } \\
\text { - Aí! Maluco! Toma na cara e segura } \\
\text { isso aqui, ó! Viado do caralho. (p. 64) }\end{array}$ \\
\hline
\end{tabular}

As ocorrências desses itens lexicais são, a nosso ver, indicativas das vozes presentes nos textos e indiciam as personae sociais reconhecíveis pelos traços linguísticos característicos que apresentam. Buscaremos mostrar, a partir dos dados acima, como esses traços são usados pelo autor para caracterizar as personae presentes em Capão Pecado. Passamos agora a comentar o uso de cada vocábulo.

\section{Mano}

Conforme pode ser observado a partir dos dados dispostos horizontalmente na Tabela 1, a palavra mano é a que tem maior frequência nos dados analisados, ocorrendo 82 vezes no total, sendo que em 54 (66\%) ocorrências ela funciona como marcador conversacional (na representação da fala das personagens).

Também é a palavra que mais ocorre (em comparação com cara, amigo, truta, maluco) na fala das personagens - 71 vezes, seja como marcador conversacional - 54 vezes, seja como forma de referência à terceira pessoa 17 vezes. Essas comparações serão mais explicitadas no final desta seção, quando faremos uma apresentação conjunta das ocorrências dos cinco vocábulos.

Percebe-se, ainda, que mano é usada na maioria das vezes como marcador conversacional/vocativo na fala das personagens, e é o vocábulo preferido como forma de referência das personagens à terceira pessoa. Já na fala do narrador o vocábulo aparece com menos frequência - apenas 11 vezes (13\%), contra 17 vezes (21\%) na fala das personagens desempenhando a função de referência à terceira pessoa.

Vejamos o gráfico 1, abaixo.

Gráfico 1 - Tipos de ocorrências da palavra mano

\begin{tabular}{|c|c|c|c|c|c|c|c|}
\hline \multirow{2}{*}{$\begin{array}{c}\text { Item } \\
\text { lexical }\end{array}$} & Narrador (3P) & \multicolumn{4}{|c|}{ Personagens } & $\begin{array}{c}\text { Total de } \\
\text { ocorrências do } \\
\text { item }\end{array}$ \\
\cline { 3 - 7 } \\
mano & 11 & $13 \%$ & 17 & $21 \%$ & \multicolumn{2}{|c|}{$\begin{array}{c}\text { Marcador } \\
\text { conversacional/Vocativo }\end{array}$} & 54 \\
\hline
\end{tabular}




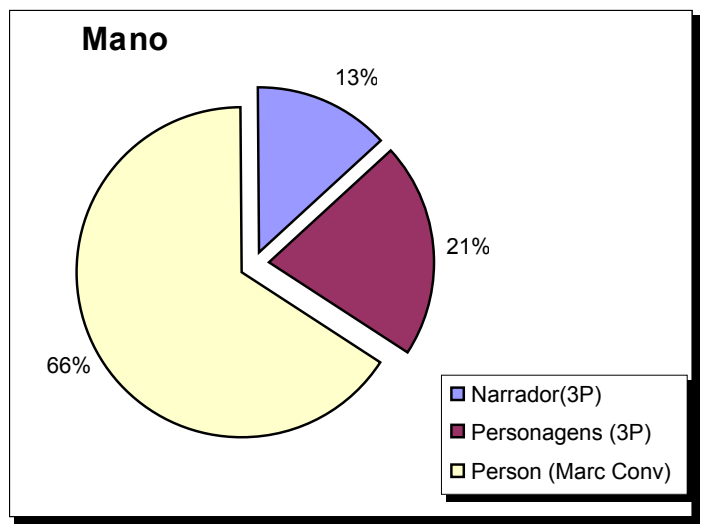

Conforme se pode verificar, das 82 vezes em que mano aparece nos dados, em $66 \%$ delas (54 ocorrências), a palavra funciona como um marcador conversacional/vocativo e apenas em 34\% ela serve para fazer referência à terceira pessoa do discurso. No entanto, o que mais nos interessa nesses dados é a comparação entre os usos que o narrador e as personagens fazem de mano para referência à terceira pessoa. Se compararmos o uso que o narrador faz com o uso das personagens, veremos que mano ocorre com maior frequência na fala das personagens. Na verdade não é a quantidade das ocorrências que nos interessa, e sim o que esses números parecem indicar em relação ao modo como o autor percebe os traços lexicais marcantes da fala dos manos e estiliza essa fala.

\section{Cara}

Outra palavra usada para se fazer referência à terceira pessoa do discurso e também como marcador conversacional é cara, que aparece em um total de 19 vezes. Vejamos então a distribuição da palavra entre o narrador e as personagens. Em 32\% (6) das ocorrências, cara é usada pelo narrador para fazer referência à terceira pessoa, ao passo que, em $47 \%$ das ocorrências (9), cara é usada quando as personagens fazem referência à terceira pessoa. E em $21 \%$ (4), a palavra é usada como marcador conversacional.

Gráfico 2 - Tipos de ocorrências da palavra cara

\begin{tabular}{|c|c|c|c|c|c|c|c|}
\hline \multirow{2}{*}{$\begin{array}{c}\text { Item } \\
\text { lexical }\end{array}$} & \multirow{2}{*}{ Narrador (3P) } & \multicolumn{4}{|c|}{$\begin{array}{c}\text { Personagens } \\
\text { ocorrências do item }\end{array}$} \\
\cline { 4 - 8 } & \multicolumn{3}{|c|}{$\begin{array}{c}\text { Marcador } \\
\text { conversacional/Vocativo }\end{array}$} & \\
\hline cara & 6 & $32 \%$ & 9 & $47 \%$ & 4 & $21 \%$ & 19 \\
\hline
\end{tabular}

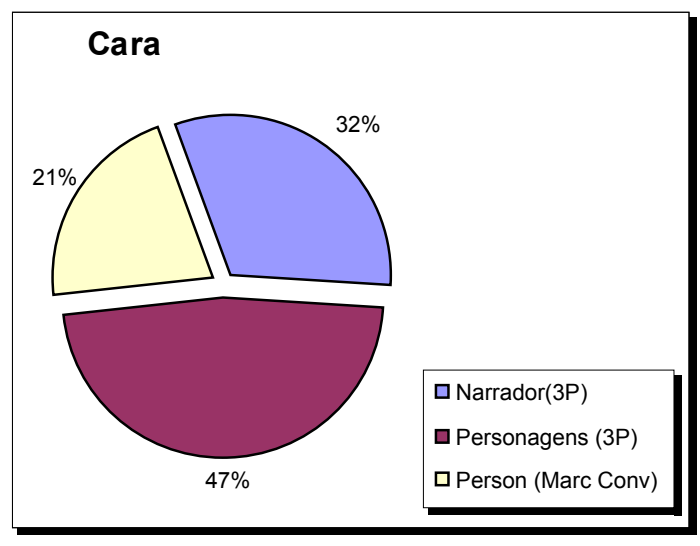

Percebemos que a frequência e a distribuição das ocorrências de cara nos discursos do narrador e das personagens é menos saliente e pouco marcada em relação às demais palavras do grupo analisado (discutiremos a correlação frequência/marcação logo a seguir).

\section{Amigo}

Já a palavra amigo aparece 52 vezes no corpus analisado, sendo 50 delas ( $96 \%$ das ocorrências) na fala do narrador e apenas 2 vezes $(4 \%)$ na fala das personagens. 
Gráfico 3 - Tipos de ocorrências da palavra amigo

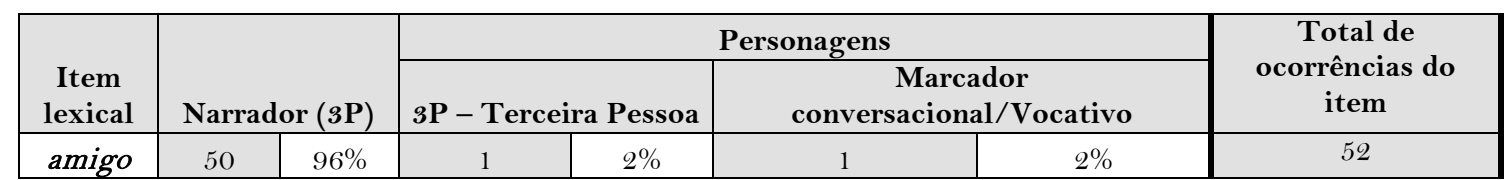

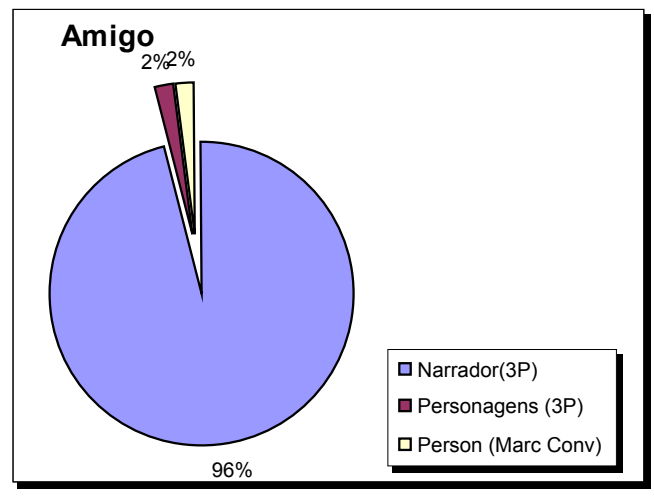

Uma observação interessante é que a única ocorrência de amigo como marcador conversacional é a que aparece transcrita abaixo:

Exemplo (7)

- [...] Logo, logo eu vou terminar com ela, num vou ficar com alguém que eu não gosto mais.

- Bom, mas aí é você que decide, mano, eu não posso fazer nada, chega nela e explica a situação.

- Você pode fazer sim, amigo. Fica de olho lá na firma, se ela se interessar por alguém [...], você me conta (p. 56).

Essa única ocorrência nos faz pensar nas razões de sua existência. Embora o trecho possibilite interpretar mano e amigo como sinônimos no contexto, e, portanto, intercambiáveis, cremos que uma interpretação possível para a ocorrência de amigo e não de mano diz respeito à relação de amizade e principalmente de respeito que se espera de um amigo, pois, como podemos observar pela comparação com as outras ocorrências de amigo e mano, usar a primeira como vocativo parece indiciar uma relação não só de maior intimidade, mas também de maior respeito e consideração entre os interlocutores. Isso ilustra a ideia defendida por Coupland (2001, p. 190) de que as formas alternativas de se dizer algo, ainda que tenham similitude referencial, remetem a outros processos simbólicos no discurso.

\section{Truta}

Já a palavra truta é a que tem menor número de ocorrências entre as que analisamos. Ocorre apenas 11 vezes, sendo que a maioria absoluta (8 ocorrências) funciona como marcador conversacional/vocativo. Inicialmente, pode-se considerar que truta é um sinônimo possível de mano, no entanto, a partir da interpretação do exemplo (8), a seguir, depreendemos que truta refere-se ao tratamento dado à pessoa com quem se tem maior intimidade e que faz parte de um grupo mais restrito de relacionamento.

Exemplo (8)

- Narigaz, Narigaz! Escuta, meu.

- Ahn... Eu tô ouvindo sim, é que eu tava pensando num bagulho aqui... mas aí, o mano que morreu era truta seu, Matcherros?

- Que nada, era um corintiano! Sabe, era sossegado... (p. 92).

Gráfico 4 - Tipos de ocorrências da palavra truta

\begin{tabular}{|c|c|c|c|c|c|c|c|}
\hline \multirow[b]{2}{*}{$\begin{array}{c}\text { Item } \\
\text { lexical }\end{array}$} & \multirow{2}{*}{\multicolumn{2}{|c|}{ Narrador (3P) }} & \multicolumn{4}{|c|}{ Personagens } & \multirow{2}{*}{$\begin{array}{c}\text { Total de } \\
\text { ocorrências do } \\
\text { item }\end{array}$} \\
\hline & & & \multicolumn{2}{|c|}{ 3P - Terceira Pessoa } & \multicolumn{2}{|c|}{$\begin{array}{c}\text { Marcador } \\
\text { conversacional/Vocativo }\end{array}$} & \\
\hline truta & 1 & $9 \%$ & 2 & $18 \%$ & 8 & $73 \%$ & 11 \\
\hline
\end{tabular}




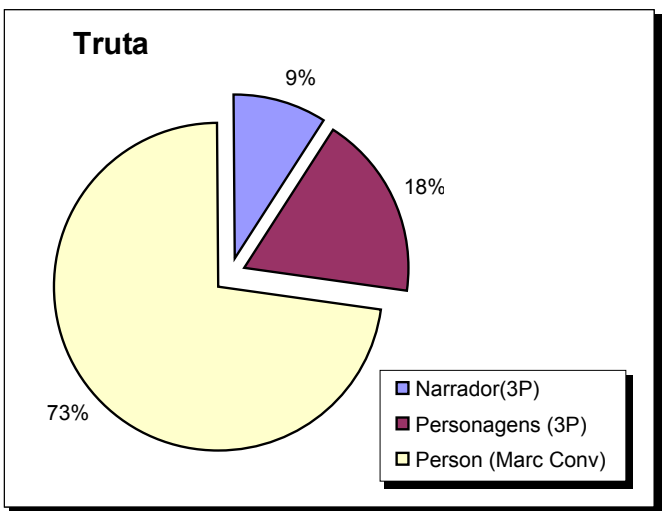

Embora truta apareça 11 vezes nos dados, ela é a que menos aparece, considerando-se o total de ocorrências dos outros itens lexicais.

\section{Maluco}

A palavra maluco é a que aparece em segunda posição na preferência de uso na fala das personagens para se referirem à terceira pessoa, perdendo apenas para mano, que é a mais usada na fala das personagens, tanto para se referirem à terceira pessoa, quanto para se referirem à segunda pessoa (marcador conversacional/vocativo).

Gráfico 5 - Tipos de ocorrências da palavra maluco

\begin{tabular}{|c|c|c|c|c|c|c|c|}
\hline \multirow[b]{2}{*}{$\begin{array}{l}\text { Item } \\
\text { lexical }\end{array}$} & & & \multicolumn{4}{|c|}{ Personagens } & \multirow{2}{*}{$\begin{array}{c}\text { Total de } \\
\text { ocorrências do } \\
\text { item }\end{array}$} \\
\hline & \multicolumn{2}{|c|}{ Narrador $(3 \mathrm{P})$} & \multicolumn{2}{|c|}{ 3P - Terceira Pessoa } & \multicolumn{2}{|c|}{$\begin{array}{c}\text { Marcador } \\
\text { conversacional/Vocativo }\end{array}$} & \\
\hline maluco & 5 & $25 \%$ & 10 & $50 \%$ & 5 & $25 \%$ & 90 \\
\hline
\end{tabular}

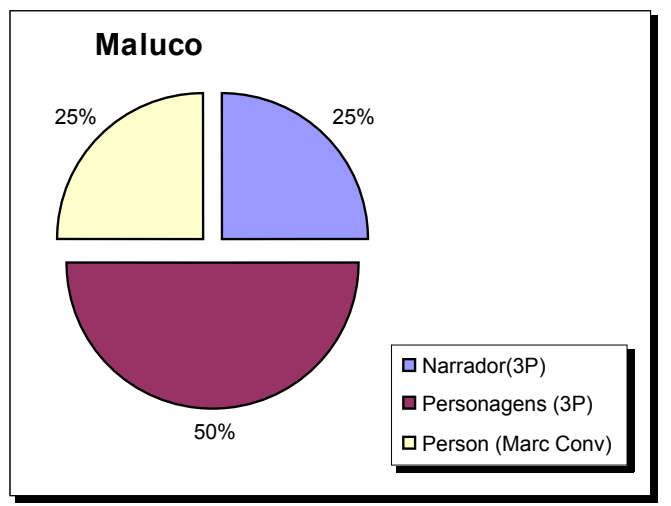

A análise do exemplo (9) a seguir nos ajudará e entender o significado do uso de maluco em Capão Pecado. Vejamos, então, o exemplo.

$$
\text { Exemplo (9) }
$$

Turcão abriu a porta, estava com um litro de conhaque na mão e uma pistola na cinta como sempre. Ele o mandou entrar, Burgos entrou, cumprimentou uns malas encostados na parede e disse:

- Tá tudo pela órdi!

Turcão fingiu não entender o esclarecimento e perguntou:

- Pela órdi o quê cumpádi?

- Ah! Num vem com essa não, maluco, sem gozação, a parada tá feita.

$[\cdots]$

- Tô ligado, num fica abalado não, maluco, a parada tá ali, com esse serviço que você realizou e a parada que você me deu, completou o pagamento, é só pegar a sacola e conferir.

Burgos entrou no banheiro e saiu de lá com a sacola, a abriu em frente aos malas e conferiu a mercadoria em voz alta. 
- Revólver calibre 38, cano de duas polegadas, revólver 19 calibre 357, Magnum em aço inoxidável, cano de duas polegadas, mas tá faltando a espingarda.

Turcão o fitou e disse que a espingarda que ele pediu era de caça e que os malucos da civil não tinham, por isso ele havia arrumado algo pra substituir.

$[\cdots]$

Burgos não gostou muito da ideia, mas viu que os malas estavam de pé, e de repente tudo aquilo estava parecendo uma trairagem, pegou as granadas rapidamente, colocou duas na bolsa e ficou com uma na mão, Turcão estranhou o ato e perguntou o porquê do medo, Burgos respondeu que não conhecia os malucos e que se fosse trairagem tudo iria pelos ares. Turcão deu uma longa risada e falou pra ele fica a pampa, pois os malucos que tavam ali eram tudo da polícia lá de Heliópolis, e que tavam ali acertando uma parada de pó. Burgos não hesitou e saiu rapidamente do barrado, com a granada na mão e a maldade no pensamento. (p. 87).

No exemplo (9), percebe-se que há uma interação altamente tensa, pois Burgos (personagem "sangue no olho", que matou diversas pessoas no decorrer da história) está no barraco de Turcão (um "vendedor" de armas e drogas), com quem tem alguns "negócios" a resolver. Chegando ao barraco de Turcão e notando presença de pessoas que não conhece, suspeita que possa ser alguma armação. Perceba-se que o uso de maluco é preferido aqui, em detrimento de outras formas equivalentes (mano, truta, amigo, cara), já que, das vinte ocorrências do lexema no corpus, cinco delas estão no trecho transcrito.

Comparando o contexto interacional em que ocorre, notamos que maluco revela certo distanciamento (senão uma tensão na interação, como o exemplo (9) indica) entre os sujeitos referidos por essa palavra, seja em terceira pessoa, seja em segunda pessoa (marcador conversacional).

\section{Síntese dos dados}

Apresentando os dados em conjunto, temos a tabela 2 (agora com uma leitura comparativa das ocorrências na vertical) e o Gráfico 6.

Tabela 2 - Ocorrências dos vocábulos mano, cara, amigo, truta, maluco

\begin{tabular}{|l|c|c|c|c|c|c|c|c|}
\hline \multirow{2}{*}{$\begin{array}{c}\text { Item } \\
\text { lexical }\end{array}$} & \multirow{2}{*}{\begin{tabular}{l} 
Narrador (3P) \\
\cline { 3 - 9 }
\end{tabular}} & \multicolumn{3}{|c|}{ 3P - Terceira Pessoa } & \multicolumn{2}{|c|}{$\begin{array}{c}\text { Marcador } \\
\text { Total de } \\
\text { ocorrências de } \\
\text { cada item }\end{array}$} \\
\hline mano & 11 & $15 \%$ & 17 & $43 \%$ & 54 & $75 \%$ & 82 & $45 \%$ \\
\hline cara & 6 & $8 \%$ & 9 & $23 \%$ & 4 & $6 \%$ & 19 & $10 \%$ \\
\hline amigo & 50 & $69 \%$ & 1 & $3 \%$ & 1 & $1 \%$ & 52 & $28 \%$ \\
\hline truta & 1 & $1 \%$ & 2 & $5 \%$ & 8 & $11 \%$ & 11 & $6 \%$ \\
\hline maluco & 5 & $7 \%$ & 10 & $26 \%$ & 5 & $7 \%$ & 20 & $11 \%$ \\
\hline
\end{tabular}

Gráfico 6 - Ocorrências dos vocábulos mano, cara, amigo, truta, maluco

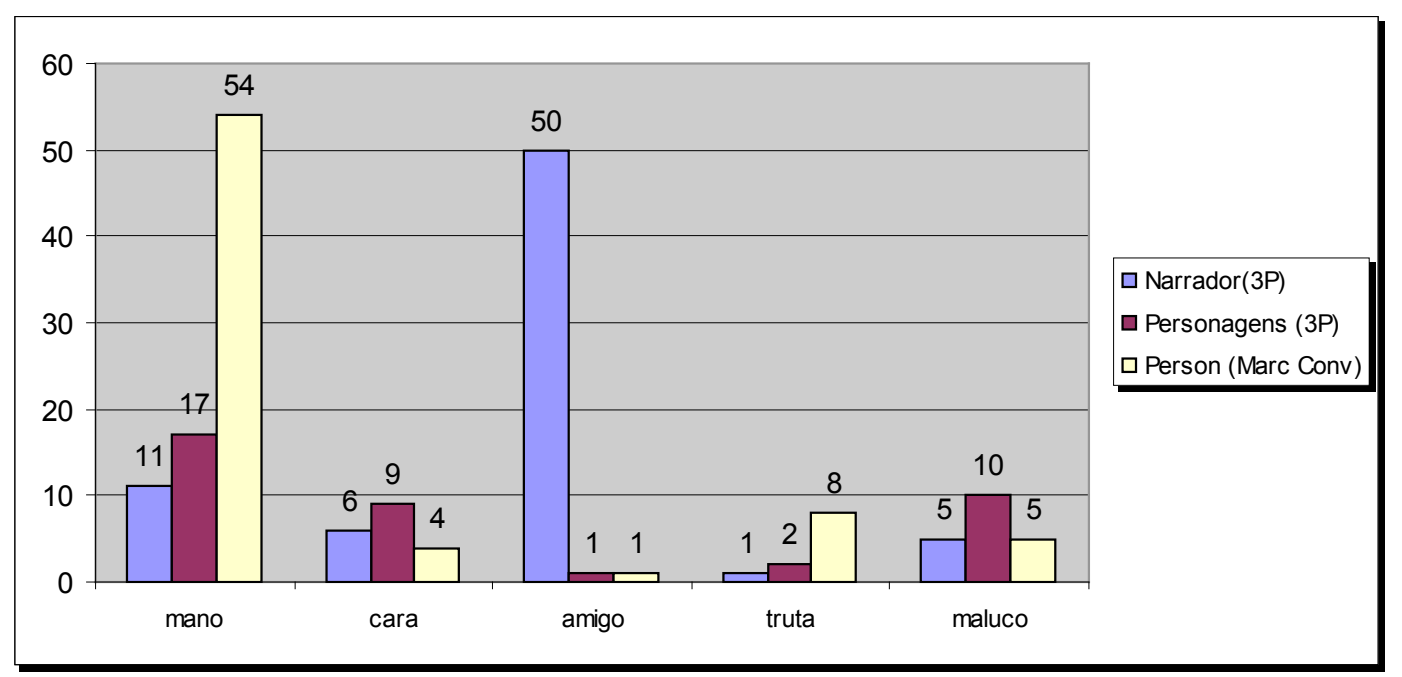


Vejamos, então, como poderíamos fazer a análise da Tabela 2, lendo e comparando os dados no sentido vertical, de modo que possamos visualizar a preferência vocabular do narrador e das personagens em relação aos cinco lexemas tratados (mano, cara, amigo, truta e maluco). Chamam a atenção nesses dados dois comportamentos em relação aos itens analisados: o primeiro diz respeito à baixa frequência de truta e maluco na fala do narrador e à alta frequência de amigo nessa mesma fala; o segundo dado que chama a atenção é a alta frequência de mano e maluco nas falas das personagens.

Com relação à análise quantitativa, é útil o princípio proposto por Givón (2001, p. 37) acerca da correlação existente entre frequência de uma variante e sua marcação: "a categoria marcada é menos frequente no texto e a não marcada é mais frequente". Seguindo esse princípio, constatamos que, para o estilo do narrador, a variante não marcada (porque mais frequente) é amigo, ao passo que a marcada é truta (já que é a menos frequente). Com relação à fala das personagens, ocorre situação quase inversa, pois amigo é a ocorrência menos frequente (portanto, é a forma marcada nesse grupo), tanto em seu uso para se referir à terceira pessoa, quanto no uso para se referir à segunda pessoa (marcador conversacional/vocativo). Já mano, por ser a que mais ocorre na fala das personagens, é a forma não marcada nesse grupo. Ao colocarmos os cinco vocábulos num eixo contínuo de marcação, temos a seguinte distribuição:

Eixo da marcação na fala do Narrador

\begin{tabular}{ccccc}
- marcado & & & & + marcado \\
\hline $\begin{array}{c}\text { amigo } \\
50\end{array}$ & mano & cara & maluco & truta \\
& 11 & 6 & 5 & 1
\end{tabular}

Eixo da marcação dos Marcadores conversacionais na fala das personagens

\begin{tabular}{ccccc}
- marcado & & & + marcado \\
\hline mano & truta & maluco & cara & amigo \\
54 & 8 & 5 & 4 & 1
\end{tabular}

Eixo da marcação da referência à terceira pessoa na fala das personagens

\begin{tabular}{ccccc}
- marcado & & & + marcado \\
\hline mano & maluco & cara & truta & amigo \\
17 & 10 & 9 & 2 & 1
\end{tabular}

Se considerarmos o conjunto total das ocorrências dos vocábulos usados pelas personagens teremos o seguinte quadro, com seu respectivo Eixo de Marcação:

\begin{tabular}{|l|c|c|}
\hline \multicolumn{3}{|c|}{ Personagens (TOTAL) } \\
\hline mano & 71 & $63 \%$ \\
\hline cara & 13 & $12 \%$ \\
\hline amigo & 2 & $2 \%$ \\
\hline truta & 10 & $9 \%$ \\
\hline maluco & 15 & $14 \%$ \\
\hline Total & $\mathbf{1 1 1}$ & $\mathbf{1 0 0} \%$ \\
\hline
\end{tabular}

Eixo da marcação na fala das personagens (Total)

\begin{tabular}{ccccc}
- marcado & & & & + marcado \\
\hline mano & maluco & cara & truta & amigo \\
71 & 15 & 13 & 10 & 2
\end{tabular}

Considerando esses "Eixos de Marcação" somos levados a pensar que é possível fazer uma associação que ligue o uso de amigo ao discurso do narrador e às demais características linguísticas desse discurso: maior 
proximidade com a norma padrão (ocorrência de concordância verbal e nominal, colocação pronominal, uso do pretérito mais-que-perfeito do indicativo, etc.). Inversamente, as ocorrências de mano, maluco, truta estariam relacionadas a ambientes linguísticos cujas manifestações estão mais próximas do não padrão (ou popular): a ausência de concordância verbal (sujeito plural com verbo singular) e nominal (marcação de plural apenas no primeiro elemento do sintagma nominal), destoando da norma-padrão.

\section{CONCLUSÕES}

A partir da análise das ocorrências de alguns itens lexicais em Capão Pecado buscamos identificar as diferentes vozes que se manifestam por meio dos registros presentes no livro. Percebemos que os usos linguísticos dessas vozes não só marcam e afirmam as identidades percebidas e perceptíveis dos chamados manos, como também indiciam personae sociais envolvidas na interação.

Assim, o uso de determinadas formas referenciais e não de outras possíveis num dado contexto revelam uma consistência de registros que estão diretamente relacionados com a situação e a posição social que os sujeitos fazem aparecer por meio de suas interações intragrupo.

Conforme tentamos mostrar a partir de alguns dados, os modos de referência aos membros dos grupos por meio dos lexemas mano, cara, amigo, truta e maluco são iconizadores tanto de traços da identidade linguística do grupo, como também de "grau de pertença" ao grupo. Maluco, por exemplo, geralmente se refere a indivíduos que são de fato menos próximos do falante, ou a indivíduos com os quais o falante quer manter certa distância.

Além desses aspectos, tentamos formular também uma correlação entre frequência e marcação de alguns lexemas em relação ao dialeto dos manos. Notamos, assim, que amigo, por ser forma marcada no dialeto usado pelos manos e não marcada no discurso do narrador, faz com este, ao mesmo tempo que se afirma como pertencente ao grupo dos manos, mostra que também partilha características linguísticas de outros modos de falar, menos estigmatizado socialmente.

\section{REFERÊNCIAS}

AGHA, Asif. Voice, Footing, Enregisterment. Journal of Linguistic Anthropology, v. 15, n. 1, p. 38-59, 2005. Disponível em: < http://dx.doi.org/10.1525/jlin.2005.15.1.1>. Acesso em: 12 jun. 2006

. Language and social relations. Cambridge: Cambridge University Press, 2007.

BAKHTIN, Mikhail Mikhailovich. Discourse in the novel. In: The dialogic imagination. Tradução de Caryl Emerson e Michael Holquist. Austin: University of Texas Press, 1981. p. 259-423.

BAKHTIN, Mikhail. Estética da criação verbal. Tradução [a partir do francês] Maria Ermantina Galvão Pereira. São Paulo: Martins Fontes, 2000.

BELL, Allan. Language style as audience design. Language in Society, v. 13, n. 2, p. 145-204, Jun. 1984. Disponível em: <http://www.jstor.org/stable/4167516>. Acesso em: 14 jun. 2011.

BENTES, Anna Christina. É nois na fita: a formação de registros e a elaboração de estilos no campo da cultura popular urbana paulista. Projeto de pesquisa, 2008 (mimeo).

. "Tudo que é sólido desmancha no ar": sobre o problema do popular na linguagem. Gragoatá, n. 27, p. 117-134, 2. sem. 2009.

COUPLAND, Nikolas. Language, situation, and the relational self: theorizing dialect-style in sociolinguistics. In: ECKERT, Penelope; RICKFORD, John R. (Ed.). Style and sociolinguistic variation. Cambridge: Cambridge University Press, 2001. p. 185-210.

Style: language variation and identity. Cambridge: Cambridge University Press, 2007.

ECKERT, Penelope. Variation, convention, and social meaning. Paper presented at the Annual Meeting of Linguistic Society of America, Oakland, CA, Jan. 7 2005. Disponível em: <

http://www.stanford.edu/ eckert/EckertLSA2005.pdf>. Acesso em: 20 mar. 2013. 
ECKERT, Penelope; RICKFORD, John R. (Ed.). Style and sociolinguistic variation. Cambridge: Cambridge University Press, 2001. [Tradução brasileira (coordenada por Anna Christina Bentes): Estilo e variação sociolinguística. São Paulo: Cortez, no prelo.]

FERRÉZ. Capão Pecado. Rio de Janeiro: Objetiva, 2005. [Primeira edição: 2000].

GIVÓN, Talmy. Syntax: an introduction. Vol. 1. Amsterdam/Philadelphia: John Benjamins, 2001.

IRVINE, Judith. "Style" as distinctiveness: the culture and ideology of linguistic differentiation. In:

ECKERT, Penelope; RICKFORD, John R. (Eds.). Style and sociolinguistic variation. Cambridge: Cambridge University Press, 2001. p. 21-43.

; GAL, Susan. Language ideology and linguistic differentiation. In: KROSKRITY, P. V. (Ed.).

Regimes of language: ideologies, polities, and identities. Santa F: School of American Research Press, 2000. p. $35-84$.

LABOV, William. Padrões sociolinguísticos. Tradução de Marcos Bagno, Maria Marta Pereira Scherre e Carolina Rodrigues Cardoso. São Paulo: Parábola, 2008. [Original: 1972].

NASCIMENTO, Érica Peçanha do. "Literatura Marginal": os escritores da periferia entram em cena. 2006. 211 f. Dissertação (Mestrado em Antropologia Social) - Faculdade de Filosofia, Letras e Ciências Humanas da Universidade de São Paulo, São Paulo, 2006.

RICKFORD, John R.; ECKERT, Penelope. Introduction. In: ECKERT, Penelope; RICKFORD, John R. (Ed.). Style and sociolinguistic variation. Cambridge: Cambridge University Press, 2001. p. 1-18.

RISSO, Mercedes Sanfelice; SILVA, Giselle M. O.; URBANO, Hudinilson. Traços definidores dos marcadores discursivos. In: JUBRAN, Clélia C. A. S.; KOCH, Ingedore G. V. (Orgs.). Gramática do português culto falado no Brasil. Vol. 1: Construção do texto falado. Campinas: Ed. Unicamp, 2006. p. 403-425.

Recebido em 04/06/13. Aprovado em 24/o9/13. 